\section{Lembaran Sejarah}

\title{
Malaise dan Lambang Kekayaan Ekonomi Penguasa Lokal di Palembang, 1929-1942
}

\section{DEDI IRWANTO}

Universitas Gadjah Mada

\begin{abstract}
This is an article on economic history, particularly on the economic growth of Palembang's Uluan local elites. But the main focus of the article is to understand and interpret other phenomenon that appeared as the product of that economic growth; its social-cultural implications that was present as a social reality of those economic conditions. It focuses on the creation of emblems of symbolic power in its political and economic manifestations. The emblems of economic wealth is seen as a symbol. As a symbol, this emblem represented meanings with several important functions, not merely as material collection, but also through a sociocultural lense; as the effort to create and contest with its peers or as an asimilative or adaptive process and a process of resistance to other groups that are 'above' its structure. The symbolic emblems of local power changed during the depression era of 1929. In a period where significant amount of wealth was lost, the uluan Palembang bucked the trend and appeared as new money (orang kaya baru) with all their new atributes of wealth.
\end{abstract}

\begin{abstract}
Abstrak
Tulisan ini sejatinya adalah bentuk lain dari sejarah ekonomi, tentang pertumbuhan ekonomi para elit lokal di Uluan Palembang. Namun titik berat kajiannya adalah suatu usaha untuk melihat dan menafsir fenomena lain sebagai ekses dari pertumbuhan ekonomi tersebut, yakni implikasi sosial budayanya, yang hadir dalam realitas sosial dari sebuah kondisi ekonomi tersebut. Kajian utamanya adalah membicarakan penciptaan lambang-lambang kuasa simbolik, baik politis maupun ekonomisnya. Oleh karena itu lambang kekayaan ekonomi dipandang sebagai suatu simbol. Sebagai simbol, lambang ini merepresentasikan makna dengan memiliki beberapa fungsi penting, tidak saja sebagai pemupukkan materi semata, yang berfungsi membedakan diri, namun juga dapat dimaknai secara sosio-kultural, sebagai usaha konstelasi dan kontestasi pada entitas "sejajarnya" atau usaha reposisi asimilatif dan proses adaptatif sekaligus resistensif pada entitas lain yang ada "di atas" strukturnya. Lambang-lambang kuasa simbolik para penguasa lokal ini kemudian mengalami perubahan, terutama ketika mendapat tempatnya pada masa malaise, depresi ekonomi tahun 1929 yang dianggap penurunan kemakmuran, namun tidak di uluan Palembang karena penguasa lokal mampu tumbuh dan muncul sebagai orang-orang kaya baru dengan berbagai atribut kemakmurannya.
\end{abstract}

Keywords: emblem; wealth; symbolic power; puyang; lifestyle

Kata Kunci: lambang; kemakmuran; kuasa simbolik; puyang; gaya hidup 


\section{Pengantar}

Pedalaman Palembang, secara politis dikenal dengan istilah wilayah uluan, sebagai sebuah dikotomis dari wilayah iliran, ibukota Palembang. Uluan Palembang dianggap wilayah "taklukan" dari penguasa di iliran, namun menariknya uluan merupakan tanah yang masih memiliki kekuatankekuatan otonom dan merdeka. Palembang sebagai daerah pusatnya hanya butuh sebuah "pengakuan" saja, dan uluan-uluan itu "mengakui" dalam bentuk konsep ritual milir sebah. Sekali-sekali, terutama sekali setahun dalam bulan ramadhan, menjelang lebaran, milir sebah, mengilir datang ke pusatnya di Palembang, sambil membawa barang-barang upeti gegawaan, hasil bumi daerah uluan, untuk dipersembahkan kepada penguasa di pusat. Sebagai imbalannya, pusat akan memberi perlindungan kepada daerah-daerah uluan yang mengadakan milir sebah.

Daerah otonom, di uluan ini, terpilah-pilah dan terpisahkan satu sama lain dalam bentuk pemerintahan kemargaan, marga. Marga ini berbentuk sebuah wilayah yang lebih banyak ditentukan berdasarkan wilayah administrasi genealogis, seketurunan. Wilayah uluan Palembang dikuasai oleh elit-elit para "orang besar" dan "orang kaya” yang umumnya berasal dari satu kekuatan saja, yakni para pasirah. Mereka ditempatkan sebagai "orang besar" karena struktur politik dan "orang kaya" karena sistem ekonomi yang terbentuk sedemikian rupa. Sebagai "orang besar" pasirah memiliki dua peranan dalam masyarakatnya, yakni sebagai kepala pemerintah, kedudukannya adalah pemimpin politik marga dan sebagai kepala adat, kedudukannya sebagai pemimpin sosial. Kemakmuran komersial didaerahnya masing-masing menyebabkan mereka dapat tumbuh sebagai agen perdagangan, selain penguasa lokal, dalam proses melibatkan arus barang dan jasa ke ibukota. Mereka adalah pengendali-pengendali perdagangan di uluan, muara-muara sungai masing-masing.

Menariknya, sebagai "orang besar", sekaligus "orang kaya” ditingkat lokal para pasirah berusaha membedakan diri dari masyarakat lain dalam marganya, sekaligus usaha kontestasi dengan antar pasirah lainnya, baik secara politik, ekonomi, sosial dan budaya. Pada tataran ini mereka kemudian berusaha memainkan kuasa simbolik, semacam kuasa untuk menentukan instrument-instrument pengetahuan dan ekspresi kenyataan sosial secara semena, tetapi seperti teori Bourdieu (1995: 168) yang kesemenaan tidak disadari.

Lambang-lambang sebagai simbol religio-magis, maupun religioekonomis menjadi arena visual, komunalistik, dan konkrit yang dipertontonkan dalam pertunjukkan kuasa simbolik tersebut. Lambang dihubungkan dengan hal yang melekat pada sesuatu, orang atau sekelompok orang, dalam hal ini mengacu pada manusia. Manusia pada hakaketnya adalah makhluk yang bersifat individu sekaligus sosial. Simbol dari 
lambang kekayaan para pasirah sebagai penguasa lokal di uluan Palembang dimaknai sebagai kelebihan yang dimilikinya, sekaligus ketidakmilikan dan ketidakmampuan pada sekelompok orang lainnya. Oleh karena itu, lambang ini merepresentasikan simbol perbedaan, bukan hanya sekedar materi, tetapi pada tindakan dan gerak dinamika dari sebuah kuasa simbolik yang dimainkannya. Jadi, makna ini kemudian diwujudkan dalam bentuk tindakan bersifat simbolik dan dramatis.

Lambang sebagai simbol perbedaan tersebut lahir dan membentuk struktur sosial. Struktur sosial merupakan pola perilaku dari setiap individu masyarakat yang tersusun sebagai suatu sistem. Setiap individu mempunyai ciri dan kemampuan sendiri, sehingga perbedaan tersebut memposisikan diri sebagai penyebab timbulnya perbedaan sosial. Perbedaan membentuk lapisan bertingkat, stratifikasi, dalam stratifikasi ini ukuran dalam lapisanlapisan ini memiliki tiga komponen yakni ukuran kekayaan, ukuran kekuasaan dan ukuran kehormatan, inilah yang kemudian melahirkan elitelit lokal pada suatu masyarakat. Ukuran-ukuran seperti itu yang melahirkan elit di daerah uluan Palembang, seperti kelompok politik dan ekonomi para pasirah, kelompok spiritual para dukun, kelompok agama para haji dan kelompok cendikia para pelajar terdidik. Pada tulisan ini hanya dilihat pada elit pasirah saja.

Ukuran kekuasaan sering tidak lepas dari ukuran kekayaan, sebab orang yang kaya dalam masyarakat biasanya dapat menguasai orangorang yang tidak kaya, atau kekuasaan bisa mendatangkan kekayaan. Oleh karena itu, tidak mengherankan dalam narasi Kathirithamby-Wells (1986: 256-67) "orang besar" dapat menjadi "orang kaya”. Pada beberapa kasus, terutama pendekatan agama, lambang kekayaan diidentifikasikan dengan kesederhanaan. Namun dalam perbincangan ini, ukuran kekayaan jelas berupa materi dan kebendaan dapat dijadikan ukuran penempatan posisi anggota masyarakat ke dalam lapisan-lapisan yang ada. Oleh sebab itu, secara visual dan konkrit kekayaan dapat dilihat antara lain dalam bentuk tempat tinggal, cara berpakaian, benda-benda tersier yang dimilikinya, maupun kebiasaan dalam berbelanja.

Uraian di atas menunjukkan bahwa lambang kekayaan ekonomi dipandang sebagai suatu simbol. Sebagai simbol, lambang ini merepresentasikan makna dengan memiliki beberapa fungsi penting, tidak saja sebagai pemupukan materi semata, yang berfungsi membedakan diri, namun juga dapat dimaknai secara sosio-kultural, sebagai usaha konstelasi dan kontestasi pada entitas "sejajarnya" atau usaha reposisi asimilatif dan proses adaptatif sekaligus resistensif pada entitas lain yang ada "di atas" strukturnya.

Genesis kekuasaan ditelaah oleh Wisseman Christie (1995: 235-88) ketika berbicara mengenai dunia maritim Asia Tenggara. Jaringan individu 
di luar pusat kekuasaan kerajaaan, melalui perdagangan dan memperoleh pengikut sebagai sumber dayanya dikaji oleh Watson Andaya (1993). Tulisan makalah ini berbeda dengan kedua kajian di atas, tulisan ini sejatinya adalah bentuk lain dari sejarah ekonomi, tentang pertumbuhan ekonomi para elit lokal di uluan Palembang. Namun titik berat kajiannya adalah suatu usaha untuk melihat dan menafsir fenomena lain sebagai ekses dari pertumbuhan ekonomi tersebut, yakni implikasi sosial budayanya, yang hadir dalam realitas sosial dari sebuah kondisi ekonomi tersebut.

Oleh karena itu, yang menjadi pertanyaan dalam tulisan ini adalah: bagaimana pertumbuhan awal para penguasa lokal di uluan Palembang? Lambang-lambang apa sajakah yang membentuk kuasa simbolik antar waktu mereka? Bagaimana pendukung kuasanya memaknai hal tersebut? Apakah simbol-simbol tersebut berubah, jika ya, apa yang menjadi peubah utamanya? Bagaimana dengan malaise, sebagai geger ekonomi, sosial dan budaya, terhadap simbol-simbol tersebut? Apakah makna dari simbol yang sedang berubah tersebut?

\section{Asal Usul Penguasa Lokal di Uluan Palembang}

Wilayah uluan Palembang, dikendalikan oleh raja-raja atau sultan-sultan Palembang dalam tiga basis lapisan daerah yakni sikap, kepungutan dan sindang. Daerah sikap adalah wilayah bebas pajak, yaitu marga-marga dalam Onderafdeelingen Banjoe Asin en Koeboestrekken, Onderafdeeling KomeringIlir, Onderafdeeling Ogan-Ilir, Onderafdeeling Musi-Ilir, Onderafdeeling Rawas. Lapisan berikut adalah kepungutan yang merupakan kantong-kantong pajak yakni marga-marga di Onderafdeeling Komering-Oeloe, Onderafdeeling Ogan-Oeloe, dan Onderafdeeling Moeara Doea. Sementara daerah sindang terletak di daerah perbatasan tidak dipungut pajak hanya pasirah di daerah ini diwajibkan untuk datang sekali dalam tiga tahun ke ibukota untuk menemui sultan. Marga-marga di daerah sindang ada di Onderafdeeling LematangIlir, Onderafdeeling Lamatang-Oeloe, Onderafdeeling Pasemahlanden, Onderafdeeling Tebing Tinggi dan Onderafdeeling Moesi-Oeloe.

Daerah uluan, terletak di hulu sungai wilayah pedalaman Palembang. Menurut Kathiritamby-Wells (1993: 77-96) daerah uluan adalah sumber utama emas pada wilayah dataran tinggi dan berbagai hasil hutan serta hasil pertanian di dataran rendahnya yang dibawa keluar melalui daerah hilir. Tanah di daerah hulu terbagi dalam kesatuan politik, sosial, ekonomi dan budaya yang disebut marga. Menurut Gunther (1926: 1225), marga berasal dari bahasa Sansekerta, Varga. Menurut Wilken (1891: 149-35), kesatuan marga adalah pengembangan dari satuan keturunan kekeluargaan yang mengacu pada entitas satu jurai, sementara dusun entitas lebih kecilnya yakni benulung. Sedang kampung mengacu pada entitas lebih kecil dari jurai dan benulung yakni belai. Marga pada masa prakolonial umumnya terdiri 
atas gabungan beberapa dusun, antara 6 sampai 8 dusun yang merupakan kesepakatan warga marga yang kemudian meminta persetujuan sultan untuk disahkan. Marga pada masa prakolonial dikepalai oleh seorang pasirah dengan gelar depati atau adipatih. Gelar depati untuk pasirah ini hanya diberikan kepada marga yang merdeka secara ekonomi di daerah sikap dan marga yang mampu mengumpulkan pajak melebihi target sultan di daerah kepungutan serta pasirah di marga sindang yang rutin datang sesuai jadwal dalam jangka waktu 10-15 tahun ke ibukota.

Untuk struktur pemerintahan di daerah marga, di bawah pasirah ada para keria, atau kria (kiyai aria) atau kerio, krio, krie yang mengepalai dusundusun di marga, mereka adalah elit lokal marga yang bergabung dalam apa yang disebut proatin. Di beberapa tempat keria biasanya juga digelari baginda, ginda atau lurah karena kecakapannya memerintah dusun. Kemudian ada juga yang disebut pembarab yang merupakan kepala dusun di ibukota marga yang bila pasirah berhalangan maka ia dapat menggantikannya.

Menariknya, meskipun sulit dilacak, namun dalam kajian Wilken (1888: 163-215) asal usul munculnya para penguasa lokal di uluan Palembang tidak dapat dilepaskan pada masa Sriwijaya. Adanya penunjukan, para pemimpin uluan dari penguasa di iliran dan untuk kesetiaan para kepala wilayah yang memanjang dari hulu ke hilir sungai Musi, terhadap datu, datu memberi berkat, perlindungan keamanan, menjanjikan kemakmuran, dan memberi kebebasan spiritual terhadap masyarakat uluan. Hal ini juga sebagai bentuk politis dalam mengintegrasikan wilayah yang terpisah tersebut, di mana datu dapat terlibat untuk eksploitasi sumber daya dari pedalaman uluannya.

Hal ini juga diperkuat oleh Wolters (1982: 16-18), kekuasaan pasirah yang muncul di marga sebagai warisan Sriwijaya. Sriwijaya mengatur kontribusi administrasi dalam bentuk lingkaran mandala, politik galaksi model tiga dimensi, ibukota pusat politik, daerah satelit dan daerah domainnya. Sriwijaya sebagai pusat yang kuat dan dikelilingi oleh daerah marga tidak dianeksasi secara sempit dalam arti politis. Deskripsi awal marga, secara implisit, timbul dalam penjelasan Wisseman Christie (1995: 235-88) yang juga melacaknya dari masa Sriwijaya. Berdasar bukti prasasti Kedukan Bukit dari berbagai istilah kuasa yang muncul kata huluntuhan, secara harfiah berarti budak tuan. Kata huluntuhan dianggap sebagai pinjaman dari bahasa Sansekerta bhumi, desa, sthdna, maryydda, rajya, parwwdndan, yang secara politik mengacu pada pengertian apa-apa dari wilayah propinsi, negara, kabupaten, daerah otonom sekitarnya. Istilah ini jelas mengacu untuk entitas geografis serta orang secara kolektivitas.

Fungsi ini jelas merupakan bentuk penguasaan melampaui batasbatas penguasaan yang bersifat penaklukan pribadi, karena datu dapat mengerahkan tenaga kerja uluan untuk membuat bangunan atau pertahanan 
militer dan pertanggungjawaban pengiriman produk hulu ke hilir oleh kepala wilayah di hulu. Kontrol datu seperti ini juga dalam bentuk penaatan larangan yang mereka buat untuk pembesar uluan, pemeliharaan atas tanah, hutan dan mineral sebagai bentuk hadiah dari datu. Sekaligus monopoli sepenuhnya kerajaan atas hasil hutan dan sumber berharga lainnya. Kadang barang berharga seperti rotan, darah naga, kapas, tawas, batu bezoar, sulfur, yang diperdagangkan di muara Sungai Lematang, kemudian komoditas lada, emas, rotan, lilin lebah, kayu lakar di muara hulu Sungai Musi, serta kemenyan, kapur barus, damar, gaharu, madu, gading gajah, cula badak di muara hilir Sungai Musi yang juga komoditas-komoditas ini dianggap upeti penguasa pedalaman untuk datu di iliran.

Menurut Marsden (1966/2013: 211) sebagai imbalannya, sultan memberi kiriman berbagai keperluan penduduk marga di daerah sindang seperti garam, candu dan bahan baku untuk membuat perahu. Selain itu, komoditas seperti, kain, beras, garam, opium, tembakau, gambir, sutra merah menjadi barang dagangan orang iliran dari ibukota di muara-muara sungai daerah uluan Palembang. Menariknya, marga-marga di uluan pada masa kesultanan Palembang adalah tanah yang tetap tertutup untuk orangorang asing, Eropa dan Belanda, kecuali Inggris yang bisa masuk ke Rawas, ketika membantu Sultan Mahmud Badaruddin II yang masuk ke uluan dalam melawan Belanda. Pelarangan orang asing untuk masuk ke uluan, termaktub dalam Hikayat Palembang yang dikutip Wolders (1975: 77), di mana untuk masuk ke wilayah hulu orang asing harus mendapat izin menteri Tumenggung Kertanegara:

"Kompeni.... Jikalau hendak ia pergi di Palembang bermainmain ke hulu negeri, beritahu kepada menteri Palembang. Jikalau bermain-main/berjalan atawa berperahu ke hulu negeri tiada memberitahu kepada menteri yang juluk Temenggung Kertanegara itu dibunuh orang jahat-jahat, tiada suatu bicaranya. Dan jikalau berjalan atawa berperahu ke hilir negeri, tiada suatu apa larangan."

\section{Makna Elit Penguasa Lokal bagi Masyarakat Marga-marga di Uluan Palembang pada Masa Prakolonial}

Dalam memahami kesetiaan masyarakat pendukung pasirah di marga-marga uluan Palembang, menurut Reuter (1992: 489-520) dan juga Jaspan (1964: 340), dalam menjelaskan struktur kekerabatan berdasar ideologi patrifocality dapat menjadi pendekatan tradisional dalam hal tersebut. Kelompok asal wilayah menjadi fitur dalam melihat bentuk khusus dalam melacak keturunan yang mengarah pada hubungan leluhur dalam mempertahankan ekslusifitas karakter keanggotaan sebuah masyarakat genealogis.

Pasirah sebagai kepala teritorial masyarakat pedalaman berbasis 
kerabatan menerima otoritas tinggi dari garis keturunan puyang. Menariknya, menurut Kathiritamby-Wells (1993: 77-96), masyarakat marga menerima bentuk ini dengan sukarela, sebab selain memberi rasa aman untuk serangan eksternal, pasirah juga memelihara hubungan internal dengan menggerakkan semua pembangunan marga baik balai, jalan maupun jembatan. Bagi masyarakatnya, pasirah juga sebagai lambang keadilan karena ia memegang peradilan adat sepenuhnya. Semua keputusan dan efek dari itu serta aturan yang dikeluarkan pasirah dianggap sebagai bentuk ketaatan mereka pada pasirahnya. Pasirah sebagai pemimpin marga yang otonom memiliki kedudukan penting bagi masyarakatnya, ia sering menjadi rujukan sosial ditengah masyarakatnya. Pada masa prakolonial ini, pasirah memiliki kesempatan terbatas dalam mengakumulasikan kekayaan pribadi dari para masyarakat marganya, karena mereka memiliki keterbatasan dalam hak untuk pajak dan upeti kepada masyarakat marganya. Kecuali kelebihan yang tidak terlalu besar untuk keuntungan dalam perdagangan serta bagian hasil dari pendapatan akibat ganti rugi yang ditimbulkan dari biaya peradilan.

Pada masa ini, pasirah berusaha menjaga lambang-lambang kuasanya dengan mengambil bentuk pada pemaknaan permainan religio-magis. Sebagai kekuasaan yang dibangun berdasarkan kekuatan dinasti, sebab itulah, dalam konsep kebesaran seorang pasirah, asal usul keturunan bersifat despotik menjadi penting. Puyang sebagai referensi dan identifikasi asal usul pasirah, menjadi acuan pengultusan terhadap mitos besar penciptaan seorang pasirah. Klaim kultus pribadi kebesaran leluhur seorang pasirah dilanggengkan lewat kerjasama dengan para dukun yang dianggap dapat berhubungan batin secara supranatural dengan, puyang.

Penciptaan lambang-lambang religio-magis yang bersifat mitos, menurut van Peursen dan Dick Hartoko (1976) dapat diterima, sebab mitos itu suatu yang memberi pedoman dan arah tertentu kepada sekelompok orang. Sesuatu itu berupa lambang-lambang ungkapan pengalaman manusia. Mitos mempunyai pengaruh kuat pada manusia, memberi arah kepada kelakukan manusia dan memberi pedoman kebijaksaan manusia. Lebih lanjut mitos berfungsi bagi manusia untuk menyadarkan manusia akan adanya kekuatan-kekuatan ajaib serta untuk dapat mengerti dan menghayati kekuatan ajaib sebagai kekuatan yang mempengaruhi dan menguasai alam kehidupan yang bersifat kesukuan. Mitos berfungsi sebagai perantara antara manusia dan daya-daya kekuatan alam, sehingga mampu memberi pengetahuan tentang dunia. Menurut kajian Bronson (1979: 315-37) proses kepercayaan pada adhiluhung leluhur sebenarnya merupakan bagian dari ritual Hindu melalui pengenalan klaim pengultusan yang membantu dalam penganugerahan bentuk ilahi dan royalti terhadap sifat manusia para pasirah, seperti tradisi yang ada di Asia Tenggara. Kekuatan dan prestise dinasti para pasirah di marga yang berkuasa lebih lanjut ditingkatkan pada monosimbolik 
struktur mental para pengikut, masyarakat marganya.

Pada kerangka pemikiran pengultusan seperti ini, kemudian turut melahirkan dan menciptakan, makna lain di masyarakat marga-marga uluan sebagai pendukung pasirah. Masyarakat marga-marga di uluan kemudian memiliki kepercayaan dan pandangan kuat akan adanya dunia lain. Mereka memaknai dunianya, dalam dua bentuk yang kadang paralel, terkadang juga dikotomis, dua bentuk dunia ini adalah dunia kasar yang dihuni manusia sebagai makhluk kasar dan dunia halus yang dihuni roh leluhur, makhluk halus. Bagi mereka dunia manusia yang kasar dianggap paralel dan terletak dipersimpangan jalan karena para roh leluhur dari dunia halus acapkali datang ke dunia kasar mereka hanya untuk menjadi semangat. Dalam pandangan mereka, jiwa manusia yang belum lahir, sebelum datang ke dunia kasar, diyakini berasal dari dunia halus tersebut.

Munculnya pemaknaan terhadap dunia halus yang dianggap memiliki kesamaan dengan dunia kasar, melahirkan juga pengkategorian yang sama dengan dunia kasar. Bagi mereka, masyarakat marga-marga di uluan, hirarkis tertinggi dalam dunia halus disimbolkan dengan tokoh ngawak, istilah yang sering digunakan sebagai referensi kepada orang-orang yang dianggap memiliki bakat ajaib dan daya tarik spiritual di masyarakat marganya, yang sejatinya mengacu pada sosok pasirah. Ngawak dipercaya memerintah terus menerus di alam roh, di mana tempat tersebut berada, sesekali ngawak berkomonikasi dengan manusia di dunia kasar. Menurut Barendregt (2006: 113-25), hal ini yang kemudian dianggap menciptakan sakralisasi terhadap lokalitas ngawak bermukim.

Menurut Collins (1979: 45-47), kadang prinsip-prinsip yang bersifat religio-magis ini acapkali memiliki garis lurus dengan konsep-konsep manipulatif lain tentang pemerolehan konsep calak, tindakan pintar dan tingginya pengetahuan kognitif dan ilmu. Oleh pasirah-pasirah di uluan kekuatan magis-religius ini dimaknai serta dieksploitasi dan dieksploirasi sedemekian rupa sebagai sumber utama kekuatan dalam mengatur masyarakat marganya. Masyarakatpun memaknai bahwa kebesaran dan kekuatan pasirah mereka dibantu, titisan dan jelmaan dari kekuatan yang memiliki arwah puyang, leluhurnya. Oleh sebab itu, masyarakat marga percaya bahwa leluhurnya akan membantu dalam memenuhi keinginan yang dibuat oleh keturunannya, kadang lewat perantara pasirah. Simbol pengultusan leluhur dari para pasirahnya, diberi arena dalam bentuk kunjungan ke makam puyang sebagai ritual ziarah dengan perantara dukun marga lewat aroma kemenyan yang acapkali dilakukan jika ada kelahiran bayi sebagai bentuk pelaporan perluasan keluarga. Selain tentunya, permohonan perlindungan untuk meminta bantuan leluhur, mereka sering meminta segala sesuatu dalam kesulitan hidupnya, dan bernazar, niat jika puyang dapat mewujudkan keinginannya, mereka akan datang kembali membawah 
keluarga besarnya, sedekah menyembelih ayam, kambing atau kerbau untuk membayar sumpah, janji, sangi niatnya tersebut.

Lambang religio-magis terhadap leluhur, juga diberi makna oleh pasirah dalam kontestasi dengan para pasirah marga lainnya. Ketika muncul persoalan terhadap tanah perbatasan misalnya, para pasirah seringkali memainkan klaim legitimasi mitos dalam mengaktualisasikan lahanlahan marganya. Sengketa tanah antar marga yang ada ini diselesaikan berdasarkan lambang-lambang religio-magis, dengan memanipulasi prinsip yang mengarah pada hubungan tua-muda leluhur keturunan seorang pasirah. Menarik, misalnya, asal-usul cerita seorang pasirah sering diparalelkan dengan kedudukan puyang mereka. Semakin tua roh leluhur, puyang, semakin seorang pasirah memiliki pengaruh kuat atas pasirah yang lebih mudanya.

Pada setiap kontestasi antar marga, pemaknaan dengan menarik garis ketuaan puyang leluhur pasirah marga menjadi legitimasi penting. Demikian misalnya, klaim legitimasi pasirah di marga-marga di daerah Gumai yang merasa lebih tua dibanding marga-marga yang ada di daerah Semidang. Kemudian ketika muncul pecahan marga dari Gumai, Gumai lama disebut Gumai Lembak, sedang Gumai baru dinamai Gumai Ulu, dan Gumai Talang anaknya Diwe Gumai, Puyang Ketunggalan Dusun dianggap silsilah tertinggi para pasirah di Gumai Talang, namun kedudukannya masih di bawah sang ayah, Diwe Gumai. Klaim para pasirah Gumai, walau leluhur puyangnya sama Diwe Gumai, menurut Sakai (1997: 42-66), namun leluhur puyang pasirahnya masing-masing merupakan pecahan dari leluhur yang lebih tua. Oleh sebabnya, klaim makna ketika puyang diturunkan menjadi menarik dalam melihat tua-mudanya dari lambang penciptaan religiomagis ini. Diwe Gumai yang diyakini telah diturunkan ke bumi dari negeri aras, pedesaan di atas langit, kemudian tiba di Bukit Siguntang, satu-satunya tempat di dunia di atas air. Kemudian Diwe Gumai terjebak dalam buah dan tidak bisa keluar dari itu, ia harus mendapat bantuan adiknya, Diwe Semidang, yang turun ke bumi satu malam setelah Diwe Gumai. Kemudian keduanya pergi ke wilayah Pelang Kenidai di kakai Gunung Dempo. Diwe Gumai merupakan rujukan nenek moyang pertama dalam silsilah tertinggi dalam setiap kepemimpinan pasirah di Gumai.

Menariknya dalam terciptanya lambang religio-magis dari hierarkis kepuyangan tersebut, pemaknaan legitimasi antar pasirah dan masyarakat pendukungnya di marga-marga, membentuk relasi pemaknaan pada susunan yang unik. Susunan kuasa seorang pasirah di Gumai, bersifat paralel, artinya pada batas region, otoritas seorang pasirah sebuah marga di Gumai hanya bisa menjadi jurai tue terbatas di marganya saja dan tidak bisa bertindak sebagai jurai tue untuk marga Gumai lainnya, karena posisinya dianggap masih dalam genealogis puyang keluarga, satu keluarga leluhur. Namun 
dalam hubungan ketuaan, klaim legitimasi pasirah Gumai Lembak merasa lebih tua dan dihormati oleh marga Gumai Talang. Para pasirah di margamarga Gumai juga merasa lebih tua, karena puyangnya Diwe Gumai berasal dari putra tertua dibanding keturunan pasirah di marga-marga Semidang sebagai turunan termuda, Diwe Semidang, adiknya Diwe Gumai.

Oleh karena itu, pemaknaan terhadap klaim lambang keturunan berupa simbol para puyang seorang pasirah menjadi penting ketika kuasa tersebut dibangun. Ada acuan para pasirah cenderung melacak dan mencari serta membentuk silsilah yang berawal pada kekuatan yang dibangun leluhurnya. Leluhur, para puyang pasirah diberi berbagai acuan refresentasi berilmu sakti, sehingga ada identifikasi penting bahwa nama pendiri marga, yang merupakan leluhur pasirah tersebut diidentikan dengan binatang buas, seperti Pasirah Anak Rimau, harimau untuk Marga Danau, di Onderafdeeling Komering-Ilir, termasuk legitimasi pada pertalian dengan puyang yang lebih tinggi semacam tokoh Iskandar Dzulkarnaen, Sigetar Alam, yang berkedudukan di Bukit Siguntang oleh para pasirah uluan.

Menyangkut kompetensi antar pasirah dalam sistem konfederasi marga, di uluan Palembang, menurut Marsden (1966/2013: 221) ada realita bahwa sejumlah kuasa marga lebih besar dibanding sejumlah marga disekitarnya. Hal tersebut terjadi karena sangat berhubungan dengan lambang dipatis dan adipatis yang dimiliki seorang pasirah. Maksudnya, semakin kuat seorang pasirah, maka semakin kuat marga yang diperintahnya dibanding marga lainnya. Secara politis kekuatan tersebut menyangkut kesaktian dan luas pengetahuan, serta ketenaran dan keterkenalan nama pasirah tersebut, sementara secara ekonomi, ukurannya adalah kepemilikan kekayaan ekonominya.

Pada masa prakolonial menariknya, lambang-lambang dipatis dan adipatis tersebut berupa benda-benda religio marga yang diturunkan dari generasi ke generasi pasirah. Umumnya lambang religio-magis ini adalah: piagam kuno berbentuk loyang berbahasa Jawa atau Melayu kuno, keris senimbang kuno, sebuah gelang bertahta ular, kopiah dari kulit lengkap dengan baju, topi bambam, payung perada emas, keris, pedang, tombak bertopak perak, lampit ulung, kajung seremang berbunga perada emas dari kain hitam, badong ikat pinggang, dan gong. Benda-benda regalia, pakaian dan senjata yang diwariskan secara turun temurun ini adalah pemberian dan penghargaan Sultan Palembang ketika mereka mengadakan tradisi milir sebah ke ibukota yang biasanya juga diikuti dengan pemberian gelar dipati atas kesetiaannya. Semakin lengkap barang-barang tersebut dipunyai seorang pasirah, masyarakat dan pasirah lain memaknai semakin tinggi ilmu sang pasirah tersebut. 


\section{Pemerolehan Ekonomi Pasirah Masa Kolonial}

Setelah Kesultanan Palembang dihapuskan dan diganti dengan Keresidenan Palembang pada tahun 1824. Pemerintah Kolonial Belanda mulai berusaha mengontrol dan mengendalikan pemerintahan marga di semua wilayah Keresidenan Palembang. Belanda menggantikan para jenang dengan seorang controleur berdasar Ind. Staatdblad No. 109 tahun 1827. Pada tahun 1848 Belanda mulai menempatkan ambtenaar-ambtenaar di daerah uluan Palembang. Namun pada tingkatan bawahnya, Belanda tetap membiarkan marga dikepalai oleh kepala-kepalanya sendiri, para pasirah.

Perhatian Pemerintah Hindia Belanda dalam memperbaiki struktur pemerintahan marga di uluan Palembang dilakukan dengan mengeluarkan peraturan dalam Ind. Staatblad No. 2 tanggal 1 Mei 1855 dengan tujuan menata serta mempersamakan kedudukan kesatuan-kesatuan masyarakat sebagai kesatuan teritorial, menghapus sekat wilayah sikap, kepungutan dan sindang dengan mengintegresikannya dalam pola kesatuan marga hanya semacam daerah kepungutan saja seperti yang dibentuk pemerintahan Kesultanan Palembang. Kemudian dikeluarkan juga Circulaire Residen Palembang No. 326 tanggal 27 Juli 1873 yang mempertegas pemberlakuan aturan-aturan dalam Undang-undang Simbur Cahaya untuk marga-marga di uluan Palembang. Dengan demikian di marga-marga uluan dijalankan sistem dualistik, yaitu di satu sisi mereka menerapkan hukum negara, namun pada sisi lain mereka tetap mengakui adanya hukum adat. Perbaikan aturan marga kembali dilakukan dengan keluarnya Ind. Staadblad No. 420 tahun 1916 tentang pembentukkan dewan marga serta Ind. Staadblad No. 814 tahun 1919 yang membuat aturan pemilihan langsung pasirah serta tata cara pemilihan dan syarat-syaratnya yakni laki-laki yang sudah berkeluarga, pandai baca tulis minimal tulisan rencong atau huruf hulu. Tahun 1922 keluar Besluit Residen Palembang tentang peruntukkan kas marga dan tahun 1923 keluar Besluit Residen Palembang tanggal 23 Oktober 1933 tentang rapat marga.

Hukum adat yang kuat dalam sistem kemargaan ini dapat dilihat dari diberinya kebebasan marga untuk mencari pendapatannya dalam menghidupi pemerintahan sendiri. Setelah masa transisi, menjelang awal abad ke-20, ketika Pemerintah Hindia Belanda mulai mengubah politiknya di daerah-daerah uluan Palembang, pengaruh kekuasaan Belanda mulai terasa. Belanda mulai ikut campur dalam urusan-urusan pemerintahan marga, mereka menjalankan politik pasifikasi dengan mengintensifkan kekuasaannya di seluruh wilayah bekas Kesultanan Palembang. Perubahan ini sejalan dengan mulai bergantinya sistem politik kolonial untuk daerah Keresidenan Palembang, yang pada masa transisi masih bersifat sentralisasi, kemudian berdasarkan Indische Staatblad 1903 No. 329 berganti sifat menjadi pemerintahan desentralisasi. Sebetulnya, secara kasat mata pemberlakukan desentralisasi ini menguntungkan bagi daerah uluan, namun dalam realitanya 
justru sebaliknya, sebab Pemerintah Belanda yang sebelumnya hanya bersifat pengawasan, berganti menjadi pengontrolan yang lebih melekat. Seorang controleur, kepala pemerintahan Belanda yang paling rendah pada daerah onderafdeeling, yang sebelumnya kalau berurusan dengan pasirah lewat perantara demang dan asisten demang, namun dengan berlakunya desentralisasi, controleur berhubungan langsung dengan pasirah karena penghapusan sistem distrik dan onderdistrik di daerah onderafdeeling.

Perubahan politik kebijakan Pemerintah Kolonial Belanda terhadap daerah Keresidenan Palembang, termasuk juga di seluruh wilayah Nusantara, mengakibatkan mulai terjadinya perubahan sosial budaya akibat pergantian pola politik. Perubahan politis, ekonomis, sosial, dan budaya ini tidak saja dirasakan di Gemeente Palembang, namun juga daerah-daerah uluan Keresidenan Palembang. Pada masa prakolonial, seorang pasirah hanya mendapatkan 5\% dari pajak yang dipungut untuk sultan, sehingga secara finansial penghasilan pasirah tidak terlalu mencolok dengan masyarakat. Para pasirah hanya menjadi semacam kelompok yang diupah oleh masyarakat marganya dalam menjalankan pemerintahan. Selain itu, penghasilan tambahan untuk seorang pasirah juga tergantung pada kemampuan dagang yang ia miliki dalam mengelola komoditas marganya di pasar sungai. Namun keadaan tersebut berubah ketika Belanda menerapkan sistem pajak untuk semua marga di Keresidenan Palembang. Para pasirah dan proatin yang dapat memungut pajak melebihi 50\% dari jumlah penduduk marganya, maka pasirah akan mendapatkan 20\% dari total jumlah pajak tersebut. Tetapi penghasilan yang biasanya masuk secara langsung ke kantong pasirah, kini masuk dulu ke kas marga. Gajinya diambil dari kas marga, besar kecilnya tergantung dari jumlah nominal pemasukan kas marga.

Puncak penghasilan seorang pasirah datang ketika munculnya komersialisasi di uluan Palembang, terutama untuk tanaman kopi di daerah dataran tinggi dan karet untuk daerah dataran rendah. Seperti kopi di daerah dataran tinggi Semendo yang budidayanya dipelopori oleh pasirah dengan membeli tunas dari perkebunan kopi di Pagaralam. Pasirah mendapat keuntungan dari penanaman karet, tanah talang, karena dalam aturan marga, tanah talang ini adalah milik sah pasirah. Perubahan sistem kekuasaan ini, berpengaruh juga pada pola kebijakan politik dan ekonomi, di mana Belanda mulai awal abad ke-20 mulai menjalankan politik liberal dengan sistem ekonomi "pintu terbuka", open the door politie. Akibat lebih lanjutnya, adalah mulai banyaknya orang-orang Belanda dan bangsa Barat lainnya hadir di dalam kehidupan orang-orang uluan.

\section{Ekonomi Malaise dan Kebesaran (Lain) Para Pasirah}

Pertumbuhan ekonomi akibat perubahan politik kolonial memberi ruang bagi pasirah untuk memanfaatkan kesempatan untuk kepentingan pribadi. 
Puncak pertumbuhan ekonomi pasirah sebagai elit lokal uluan Palembang datang sepanjang awal abad ke-20 dan dikala musim malaise serta setelahnya. Malaise melanda dunia sejak tahun 1929, dengan puncaknya 1930, yang berawal dari jatuhnya bursa saham di Wall Street, New York, Amerika Serikat menyebar ke seluruh dunia, termasuk Hindia Belanda. Malaise muncul akibat perbedaan besar antara kapasitas produksi dan kemampuan konsumsi produk-produk tersebut oleh masyarakat dunia.

Padahal sebelum malaise, pertumbuhan ekonomi Hindia Belanda sedang mengalami kenaikan secara siginifikan. Menurut van den Bosch (1941: 141-145), perusahaan-perusahaan dagang di Hindia Belanda sedang berkembang, mengalami kenaikan pesat dan keuntungan ganda karena permintaan besar pangsa pasar dunia terhadap produksi di Hindia Belanda. Pertumbuhan tersebut tidak lepas dari usaha kampanye Pemerintah Hindia Belanda yang berusaha menarik minat investor asing Eropa dengan menyatakan bahwa tanah Hindia Belanda merupakan wilayah terbuka bagi ekonomi dunia. Kampanye ini selain karena terbukanya terusan Suez tahun 1870, juga diikuti dengan keluarnya berbagai peraturan pemerintah yang memudahkan usaha industri, serta pembukaan lahan pertanian dan perkebunan untuk investor asing. Menurut Taylor (2003: 279), kehidupan masyarakat di Hindia Belanda sedang mengalami perbaikan status sosial, terutama golongan elit. Tercatat menurut laporan Departemen van Economische Zaken Centraal Kantoor voor Statistiek sejak tahun 1920, di Hindia Belanda ada sekitar 874 buah perusahaan industri pengelolahan makanan, minuman dan tembakau, serta 818 buah perusahaan gula. Setelah krisis terjadi penurunan perusahaan industri pengolahan makanan, minuman dan tembakau tinggal 709 buah, sementara perusahaan gula hanya 266 buah saja.

Kelesuhan ekonomi masa malaise, berpengaruh juga di Keresidenan Palembang, terutama kondisi ekonomi masyarakat kota Palembang, di mana kehidupan diikuti kondisi keuangan yang sulit. Namun untuk daerah uluan Palembang, malaise dianggap berkah dan bukan bencana yang mematikan rakyat penghasil tananam dagang di daerah uluan Palembang. Keuntungan ekonomi masih dapat mereka petik dari hasil komoditas karet dan kopi (Mestika Zed, 2003: 109). Meski menghantam perusahaan-perusahaan besar perkebunan milik Eropa, pertanian karet rakyat dan petani-petani besar lokal yang umumnya dimiliki keluarga pasirah mampu bertahan. Masa depresi ekonomi sepanjang tahun 1929-1933, justru semakin mendekatkan mereka dengan pasar dan berbagai institusi ekonomi modern lainnya. Kemudian dalam rentang waktu tahun 1934 sampai 1936, pertanian karet rakyat di uluan Palembang kembali menggeliat dengan adanya kupon karet, rubber coupon, yang mampu meningkatkan pendapatan dan daya beli penduduk uluan. Adanya gairah ini membuat perusahaan-perusahaan, terutama perusahaan Jepang, kembali mengalir ke uluan Palembang. Kupon karet 
telah mengenalkan pranata baru ekonomi uluan dalam bentuk ekonomi uang yang masuk ke pedesaan.

Seyogyanya, selama masa malaise kondisi ekonomi mestinya memiliki pengaruh pada kondisi hidup dan selera hidup yang cenderung memburuk. Ekspresi gaya hidup dengan pemenuhan lambang kemewahan hidup biasanya identik dengan masyarakat perkotaan seperti kajian Sri Margana dan Nursam (eds.) (2010). Namun kondisi dan gaya hidup sebaliknya justru terjadi di masyarakat non-perkotaan, marga-marga di uluan Palembang. Mereka mampu mengadaptasi gaya kekotaan, urban tersebut dengan baik. Ekonomi bukanlah persoalan statistik kuantitatif semata, namun juga kualitatif sebagai cerminan ekonomi. Adaptasi gaya urban terutama diperlihatkan oleh golongan penguasa lokal, para pasirah di uluan Palembang.

Para pasirah, selama masa komersialiasi pertanian, awal abad 20 sampai masa malaise, mampu memaknai diri karena keberhasilannya tidak saja menjadi big man, "orang besar", namun juga kemampuannya menjadi rich man, "orang kaya". Kedua kemampuan ini diperoleh para pasirah uluan Palembang, karena mereka dapat memanfaatkan dengan baik legitimasi atas dua kuasanya, yakni kuasa adat dan kuasa pencapaian pribadi. Kuasa adat adalah bentuk pemaknaan mereka akan kewenangan besar atas pengawasan, pemilikan dan penguasaan tanah-tanah adat dan pengolahan sumber daya marga hampir tanpa batas. Akibatnya, mereka memiliki banyak pengikut, selain pengikut secara politik, ada juga para pengikut secara ekonomi, para budak yang menurut Bambang Purwanto (1992) adalah orang-orang yang menggadaikan diri akibat tidak mampu membayar hutang yang merupakan bentuk konsekuensi dari mulai dikenalnya ekonomi uang di daerah uluan.

Kemudian kuasa pencapaian pribadi diperoleh ketika mereka mampu memaknai peluang baru yang terbuka pada masa kolonial. Peluang pertama mereka dapat ketika mereka dapat mengolah dan mengasah diri sebagai pedagang, sebagai pedagang pasirah mampu tampil sebagai agen yang menguasai jaringan dagang, tidak saja sebatas marga tetapi juga jauh ke kota. Catatan Peeters (1987: 56) tentang kemampuan pasirah Pangeran Mohammad Saleh dari Marga Cempaka di Onderafdeeling Komering-Oeloe yang berhasil membuka pabrik karet lokal di marganya dengan memanfaatkan hubungan dagang dengan konsultan pertanian Belanda D. J. G. van Setten dengan pinjam kredit berkat jasa van Setten adalah bukti menarik tentang kemampuan pasirah dalam pencapaian pribadi diperdagangan.

Kuasa pribadi kedua yang dapat dimaknai dengan baik adalah kemampuan sebagai perantara yang melayani kepentingan kolonial di tingkat marga, sehingga mereka ditempatkan sebagai aparat bawahan binnenland bestuur "tidak resmi" sejak tahun 1912. Sebagai perantara, mereka dapat mengekspresikan kebebasan yang diberikan, di satu sisi sumber pendapatan lama tetap diakui, di sisi lain mereka mulai mendapat 
keuntungan dalam pungutan pajak yang diberlakukan Belanda. Pada sistem pasirahstelsel, pasirah adalah pengelola utama hasil pajak yang didapat dari setiap penduduk dusun dan kampungnya, pajak dipungut dari semua lakilaki, sudah berumur dan berumah tangga. Pajak yan didapat menurut Elmhirst (2001: 173-83), digunakan sebagian besar untuk membiayai elit marga dan sisanya disetorkan ke Pemerintah Hindia Belanda.

Berikutnya, kuasa pencapaian pribadi yang berhasil dimaknai pasirah adalah kemampuannya mendapat tempat ketika terjadi komersialisasi pertanian di uluan. Mereka dapat menjadi pelopor penanaman baik kopi oleh para pasirah di dataran tinggi, maupun karet oleh para pasirah di dataran rendah, karena kemampuan yang didapat dalam menguasai tanah dan memperoleh bibit dari sekolah perkebunan yang dibuka dalam Keresidenan Palembang. Selain itu mereka mendapat keuntungan bila mana perusahaanperusahaan besar Eropa membuka perkebunan di lahan terlantar yang sebenarnya milik marga dan menurut adat dikuasai pasirah dalam bentuk kompensasi.

Kuasa besar secara politik dan ekonomi seperti ini menyebabkan pasirah, selain memiliki banyak pengikut tadi juga memiliki kekayaan yang melimpah dan wawasan yang lebih maju, ontwikkeld (Zed, 2003: 54). Kemakmuran yang didapat oleh masyarakat marganya, maka pasirah akan memperoleh berkali lipat dari yang didapat penduduk marganya. Ketika muncul boom karet, rubberbooms, sepanjang tahun 1912-1915 dan ketika oejan mas terjadi di uluan, sepanjang 1936-1942, maka sebagian dari pendapat boom karet dan oejan mas tersebut mengalir kesakunya. Ketika malaise melanda uluan, mereka adalah orang-orang pertama yang tidak bergeming akibat pengaruh yang disebabkan. Masa-masa ini, sebagai ekses dari kuasa adat dan kuasa pencapaian pribadi yang didapatnya, menyebabkan mereka memaknai hidup dengan berbagai lambang-lambang kekayaan bentuk "baru", dari masa sebelumnya, prakolonial.

Para pasirah yang tampil sebagai "orang besar" dan "orang kaya", memaknai diri sebagai agen-agen struktur kelas dalam hierarki berdasarkan total modal yang dimiliki, semakin banyak jumlah modal, kekayaan, yang dimiliki semakin tinggi dan dominan posisinya dalam struktur kelas tersebut. Akibatnya, para pasirah merasa memiliki ruang sosial yang bersifat habitus dalam menghasilkan praktek sekaligus apreasiasi yang terpolakan, termasuk dalam praktek konsumsi budaya dan gaya hidup, yang kemudian tercermin pada pakaian, makanan, perabot dan kepemilikan pribadinya.

Berbicara masalah lambang kekayaan ekonomi seseorang atau sekelompok orang, sebenarnya mengandung cerminan tingkah laku ekonomi masyarakat tersebut pada masanya. Pada tataran ini, ekonomi sebagai suatu entitas yang mempengaruhi suatu perubahan adalah potret yang berkenaan dengan perubahan aspek pola kehidupan yang sedang 
berubah, menyangkut kegiatan ekonomi, termasuk gaya hidup ekonomi misal pola konsumeritas yang terjadi, aktivitas ekonomi sehari-hari, cara dan model hidup ekonomi yang sedang menjadi trend, serta kecenderungan pilihan ekonomi yang ditempuh.

Narasi kegiatan ekonomi secara kualitatif dapat dilihat dari bentuk visual dalam potret kehidupannya mengacu gaya hidup untuk menggambarkan lambang kekuatan ekonomi yang ditampilkan oleh manusia. Ketika lambang-lambang ekonomi dilabelkan pada status sosial, maka akan berkenaan dengan sejumlah individu yang mempunyai sikap dan pola tindak yang mengidentik pada identitas khas yang ditampilkan dalam konfigurasi masyarakat tertentu. Pada tataran ini, status sosial merupakan sekumpulan hak dan kewajiban yang didasarkan pada stratifikasi sosial ekonomi, meliputi sisi pekerjaan dan pendidikan seseorang tersebut. Biasanya, orang yang memiliki status tinggi akan menempatkan dan ditempatkan lebih tinggi dalam struktur yang status lebih rendah dalam masyarakatnya. Oleh sebab itu, lambang ekonomi yang ditampilkan jelas merupakan gaya hidup para elitis lokal, pasirah di marga, yang tentu memiliki sisi pembeda dan membedakan diri dengan berbagai kalangan lain di uluan Palembang. Pada satu sisi sebenarnya, masih ada anggota elit di uluan Palembang, pasirah yang memiliki kebebasan untuk menempuh pilihan lain dalam memproyeksikan diri dengan kelas sosialnya, misalnya kecenderungan untuk tampil sederhana (low profile), namun sedikit sekali yang tampil seperti ini.

Lambang kekayaan ekonomi pertama yang terlihat dari elit uluan, para pasirah, adalah bentuk pakaian yang digunakan. Pakaian adalah identitas pembeda utama tampilan dan performance seseorang dalam masyarakatnya. Pakaian memainkan peranan sebagai suatu sistem bentuk dengan kualitas dan ekspresi yang bermakna yang menampakkan kepribadian atau pandangan umum suatu kelompok. Pakaian adalah lambang dari simbol wahana ekspresi si penggunanya. Sebelumnya, pakaian pasirah sebagai suatu simbol kebesaran cenderung relatif seragam dan statis, yakni hanya berbentuk kopiah air mas untuk songkok atau kopiah yang dipakainya, serta payung berwarna merah dengan warna kuning pada pinggirannya. Demikian juga dengan para proatin atau anak beras yang memakai pakaian kebesaran berupa kopiah dari rotan, resam yang dijahit dengan benang emas atau perak.

Kemudian ditambah dan sejalan dengan perubahan ekonomi pada masa malaise, di mana akses untuk membeli pakaian menjadi mudah, termasuk untuk masyarakat umum di uluan Palembang. Para pasirah kemudian beradaptasi dengan penggunaan pakaian ala Eropa, yang disebut pakaian calvinis, pakaian jas dan dasi, celana panjang katun serta sepatu kulit jenis pantovel. Namun adopsi lambang berpakaian pasirah tidak digunakan dasi, sebagai gantinya mereka menggunakan kain songket yang 
dililitkan dikepala atau dipinggang yang disebut badong. Modernisasi dalam kehidupan sosial ekonomi pada mulanya berposisi sebagai kepanjangan lambang dan gaya hidup masyarakat Eropa yang menyangkut dan berkenaan dengan asal mereka, Barat. Terbukanya sekat pemisah antar kelas sosial lewat administrasi masyarakat Eropa dengan elit pribumi, menjadikan pakaian juga sebagai politik para elit pasirah. Pertama, jika berhadapan dengan orang Eropa para pasirah menjadikannya sebagai modal simbolik dalam berhubungan, sehingga mereka bisa masuk dalam modernitas yang ditularkan Barat. Kedua, bagi seseorang pasirah pakaian seperti ini juga merupakan lambang kekayaan yang bisa juga menjadi modal kompetensi ketika terjadi kompetisi antar pasirah lainnya. Terkotak-kotaknya wilayah uluan secara demografis dan genealogis menjadi arena dalam kompetisi antar pasirah untuk mendongkrak prestise marganya.

Pakaian sebagailambang dari simbol status ekonomi diberi dan mencari bentuk dalam mode, tren dan cara berpakaian sekaligus sebagai cerminan adaptasi tinggi terhadap modernisasi oleh para pasirah tersebut. Penularan modernitas dan tren pakaian yang sebenarnya berawal ketika Pemerintah Keresidenan Palembang, memberlakukan dan memberi pakaian dinas harian untuk jabatan pasirah. Lalu kemudian karena pakaian ini menjadi lambang bagi mereka, maka setiap hari para pasirah memakai pakaian dinas ini, termasuk ketika mereka berkomunikasi dengan masyarakat marganya. Oleh karena itu, para pasirah kemudian memiliki baju dinas ini tidak satu saja, melainkan beberapa helai lainnya. Seperti halnya pakaian dinas orang untuk pegawai Belanda dan Eropa lainnya, para pasirah juga mengadopsi jas warna putih, selain warna hitam gelap. Oleh karena itu, adaptasi terhadap pakaian sebagai identitas dan uniformasasinya berjalan dengan baik, kecuali untuk aksesoris-aksesoris yang menjadi tambahan yang biasanya diperoleh sebagai lambang perhargaan atas prestasinya oleh Residen Palembang atau Gubernur Hindia Belanda.

Lambang berikut adalah gelar dan regalia kepangkatan. Gelar yang didapat adalah bentuk kinerja dan pengabdian para pasirah dengan Pemerintah Hindia Belanda. Gelar dalam kamus Jawa Kuno berarti "bentangan" atau "hamparan", sementara di uluan Palembang disebut sebagai "timbangan", "juluk" "jejuluk" atau "julukan" yang biasanya dipakai sebagai nama awal atau nama lain, alias. Namun gelar juga dipakai sebagai istilah "jabatan" atau "keahlian". Pada masa ini gelar yang didapat pasirah untuk gelar "dipati" didapat dengan Besluit Controleur, sementara untuk gelar tertinggi, "pangeran" dilakukan dengan Besluit Residen Palembang. Selain gelar, pemberian tanda jasa juga dijadikan regalia lain sebagai pelengkap pakaian, ada beberapa bentuk regalia ini, yakni bintang kecil dan bintang besar. Bintang kecil diberikan oleh controleur dan bintang besar diberikan oleh Residen Palembang. Kemudian jenis bintang ini ada bintang perak dan 
bintang emas serta bintang besi. Bintang perak diberikan oleh Controleur, bintang emas diberikan oleh residen, dan bintang besi diberikan oleh Gubernur. Regalia lain yang dimiliki pasirah adalah tongkat berlapis emas yang dianugerahkan oleh Residen Palembang.

Pemberian gelar dipati dan pangeran dari Pemerintah Hindia Belanda tersebut juga diikuti dengan tren penambahan gelar adat marga pada masing-masing pasirah, misalnya Suradilaga, Pawirakusuma, Kemalajaya, Kumalaratu, Natadiraja, Mangkualam, Mangkubumi, Mangkumarga di marga-marga onderafdeeling Komering-Oeloe dan Ogan-Oeleo. Kemudian gelar Mangkuyuda, Kramajaya, Wirajaya, Wirakrama untuk onderafdeeling Komering-Hilir dan Ogan-Ilir. Kemudian Mangkulada, Pakubuwana, Mangkuraja, Purbabuwana di Onderafdeelingen Musi-Hilir, Musi-Oeloe, Rawas, Tebing Tinggi, Pasemah Lebar, Kikim dan Lematang (van den Berg, 1894: 205-273).

Selain pakaian, lambang penguasaan kekuatan ekonomi, para pasirah di uluan Palembang adalah proses adaptasi kegiatan sehari-hari rumah tangga, terutama dalam pola makan. Salah satu yang menarik adalah perubahan dan pengenalan pola dari bentuk makan hidangan menggelar duduk di atas tikar, berganti menjadi pola makan Belanda yang dikenal sebagai rijsttafel. "rijst" nasi dan "tafel" meja, makanan di atas meja. Makanan prasmanan nasi dan lauk-pauk di atas yang ditata lengkap dengan seluruh aksesoris tempat lilin, lilin, celemek, penutup baju, dan lap.

Lambang-lambang kekayaan menjadi simbol manusia dalam memberi makna pada kehidupannya lewat medium dan ruang untuk mengekspresikan diri. Simbol dari lambang tersebut mewujud dalam bentuk interaksi diri dengan tempat, baik hiburan, plesiran, penggunaan transportasi serta penggunaan teknologi. Penggunaan transportasi yang mengacu pada plesiran adalah kepemilikian lambang kekayaan dengan kepemilikan mobil pribadi. Kendaraan motor pertama kali di Indonesia dimiliki oleh orang Inggris, John C. Potter, masinis pabrik gula Oemboel di Probolinggo tahun 1893. Sementara mobil bermotor pertama yang dimiliki orang Indonesia adalah mobil Benz yang dipunyai oleh Susuhunan Pakubuwono X dari Surakarta (Khusyairi \& Colombijn, dalam: Colombijn \& Coté [eds], 2014: 255).

Pada tahun 1929 mobil pertama hadir di Pulau Sumatera. Mobil ini milik W. Schruffner di Medan berjenis Benz. Pada tahun 1920 jumlah oto pribadi di Keresidenan Palembang belum mencapai 3.000 kendaraan dan kebanyakan masih dimiliki oleh perusahaan besar serta pejabat Belanda. Namun pada tahun 1927 jumlahnya sudah meningkat tajam mencapai 3.750 buah oto berbagai tipe dan ukuran serta tersebar hingga kepelosok dusun di uluan. Tiga tahun berikutnya mobil di Keresidenan Palembang melonjak hampir seratus persen menjadi 6.462 buah kendaraan. Menurut 
Wellan (1932: 481-489), jenis tipe kendaraan mobil di uluan bervariasi seperti mobil pribadi, vrachtauto, motorrijwielen, autobus. Merek kendaraan pun bermacam-macam mulai ford, albion, ruby, chevrolet, sampai whitesteam. Harga mobil ini berkisar antara f. 7.000 - f. 10.000. Akibatnya, semua pasirah di uluan memiliki mobil, baik pribadi maupun untuk pengangkutan barang dan orang.

Pasirah pertama di uluan yang memiliki pesawat telepon adalah Pasirah Mohammad Nuh Pangeran Anom Kusuma dari Marga Pegagan Ilir I yang diletakkan di kantor marga. Keberadaan telepon di kantor tersebut membuat kebesaran kantor marga ini cukup terkenal dalam onderafdeeling Ogan-Hilir dan Komering-Hilir. Lambang lain kekayaan pasirah di uluan Palembang adalah memiliki istri lebih dari satu. Muhammad Ali Hanafiah Pangeran Adipati pasirah Marga Lintang memiliki 6 orang istri, anaknya pasirah Neroddin Pangeran Natayuda memiliki 8 orang istri, sementara cucunya pasirah Zainuddin Pangeran Aji memiliki 5 orang istri.

Secara keseluruhan lambang dari simbol kekayaan ini terekam dengan baik dari budaya konsumsi. Sikap konsumtif kadang diposisikan tidak hanya sekedar pemenuhan kebutuhan-kebutuhan dasar dan fungsionalnya semata, melainkan juga menjadi bingkai budaya masyarakat pendukungnya. Simbolsimbol ini misalnya ditemukan dalam kegiatan hiburan perkawinan dari anak seorang elit lokal. Pada aturan adat dari Undang-undang Simbur Cahaya Pasal 34 tentang aturan dusun dan berladang dijelaskan "siapa-siapa yang berjudi atau sabung tiada dengan izin daripada yang kuasa di dalam Batanghari, kena hukuman raja". Namun menariknya dalam setiap pesta perkawinan seperti itu yang banyak dilakukan pasirah adalah kegiatan judi terselubung, dalam bentuk taruhan sabung ayam dan lelang kue (Irwanto, 2011: 97). Sabung ayam dan lelang kue di pernikahan adalah arena kontestasi antar pasirah, pemenang dari arena ini adalah menyangkut distinsi, distintion, rasa gengsi, bergengsi yaitu rasa berbeda, sekaligus rasa lebih. Lambang-lambang kekayaan penguasa lokal, para pasirah di uluan Palembang merupakan simbol dari sebuah makna tentang diklasifikasikan oleh cara mengklasifikasikan, dibedakan oleh pembeda yang dibuat. Lambang-lambang ini adalah makna dari simbol yang berkenaan dengan selera, "tinggi", "bagus", "halus" dan "berbudaya” sebagai dikotomi dari selera lain "rendah”, "pasaran”, "kasar” dan "tidak berbudaya”.

Namun menariknya, simbol-simbol terhadap lambang kemewahan (lux) tersebut, juga merupakan pencitraan diri tidak saja untuk membedakan diri dengan masyarakat marga dan kontestasi sesama pasirah di marga lainnya, namun juga kepenganutan diri dari bentuk modernitas Eropa, sekaligus pendefenisian sikap dan nilai-nilai dalam menunjukkan kekayaan serta posisi sosial para pasirah di mata orang Barat dan pengunjukan diri untuk disamakan paling tidak terlalu jauh dengan para atasannya, orang Belanda. 
Sehingga sebanarnya dalam banyak bentuk lambang-lambang kekayaan para pasirah tersebut selain adopsi elit lokal atas keinginan melepaskan "bentuk lama" dan mencoba mengganti diri ke "bentuk baru", bagi masyarakat pendukungnya, para masyarakat marga yang dipimpinnya, lambang-lambang tersebut hanyalah sebuah penegasian bahwa kepemimpinan pasirahnya sedang berubah, dari sebuah daulat rakyat prakolonial, menuju daulat tuanku masa kolonial. Dalam pandangan para penduduk marga, tangan kanan para pasirah semakin memanjang berusaha menyapa dengan ramah Belanda, sedangkan tangan kiri mereka justru memendek untuk mencekik leher warga marganya, ketika kewajiban lama tetap harus ditunaikan dan kewajiban baru bentuk resmi bernama pajak kepala berlaku. Akibatnya, roh leluhur puyang makin tercerabut dari badan para pasirah.

\section{Kesimpulan}

Penciptaan munculnya para penguasa lokal di uluan Palembang, meskipun sulit dilacak, namun tidak dapat dilepaskan pada masa Sriwijaya. Penunjukkan para pemimpin uluan oleh para datu, penguasa di iliran, sebagai bentuk politis dalam mengintegrasikan wilayah yang terpisahnya, kemudian secara ekonomis sebagai bentuk eksploitasi sumber daya terhadap uluannya. Selanjutnya, untuk menjaga kesetiaan daerah uluan, datu di iliran memberi berkat, perlindungan keamanan, menjanjikan kemakmuran, dan memberi kebebasan spiritual terhadap masyarakat uluan. Sebaliknya, para penguasa lokal di uluan sebagai tanda setia memberi upeti serta menjadi distributor utama sumber daya ke iliran.

Kuasa para pasirah di marga-marga uluan sangat otonom, untuk memahami kesetiaan masyarakat pendukung pasirah di marga-marga uluan Palembang tersebut, ideologi patrifocality dapat menjadi pendekatan tradisionalnya, artinya kelompok asal wilayah menjadi fitur dalam melihat bentuk khusus melacak keturunan yang mengarah pada hubungan leluhur untuk mempertahankan ekslusifitas karakternya. Oleh karena itu, lambanglambang yang dimainkan dalam membentuk kuasa simbolik ini adalah berbentuk religio-magis yang bersifat mitos, kebesaran leluhur pasirah dieksploitasi sedemikian rupa. Leluhur dalam bentuk, puyang dianggap referensi dan identifikasi pasirah serta menjadi acuan pengultusan terhadap mitos besar penciptaan seorang pasirah. Lambang-lambang lain kuasa simbolik yang dilanggengkan dalam bentuk benda-benda regalia marga yang diturunkan dari generasi ke generasi, seperti, piagam, keris, pedang, tombak, gelang, kopiah kulit, topi, payung, perada, lampit, kajung, badong, dan gong. Lambang-lambang ini digunakan bukan saja untuk konstelasi ke masyarakat marganya, namun juga fungsi makna kontestasi sesama pasirah di marga-marga lainnya. Para pendukung pasirah kemudian memaknai simbol dari lambang-lambang ini melebihi ekspetasinya, sehingga 
kemudian menciptakan kepercayaan dan pandangan kuat akan adanya dunia lain. Mereka memaknai dunianya, dalam dua bentuk yang kadang paralel, terkadang juga dikotomis, dua bentuk dunia ini adalah dunia kasar yang dihuni manusia sebagai makhluk kasar dan dunia halus yang dihuni roh leluhur, makhlus halus, yang sesungguhnya bentuk pelanggengan terus menerus atas kuasa simbolik yang dibangun di atas makna kepemimpinan para pasirah di marga-marga uluan Palembang.

Kemudian ketika terjadi perubahan besar, dari prakolonial ke masa kolonial, lambang-lambang kekayaan ini kemudian juga berubah. Pasirah memperoleh kekayaan dengan memanfaatkan dua hal dalam dirinya, yakni kuasa adat dan kuasa pencapaian pribadi. Kuasa adat adalah bentuk pemaknaan mereka akan kewenangan besar atas pengawasan, pemilikan dan penguasaan tanah-tanah adat dan pengolahan sumber daya marga hampir tanpa batas. Akibatnya, mereka memiliki banyak pengikut. Kemudian kuasa pencapaian pribadi diperoleh ketika mereka mampu memaknai peluang baru yang terbuka pada masa kolonial, yaitu sebagai pedagang, sebagai perantara kepentingan kolonial di tingkat marga, dan kemampuannya mendapat tempat ketika terjadi komersialisasi pertanian di uluan. Mereka berhasil tidak saja menjadi big man, "orang besar", namun juga menjadi rich man, "orang kaya”, terutama ketika perekonomian terpuruk akibat malaise. Malaise yang mampu mendekatkan mereka dengan pasar dan institusi ekonomi modern lainnya, dianggap ruang yang pas para pasirah untuk mengubah lambanglambang "lama" ke dalam bentuk lambang-lambang "baru" sebagai "orang besar", sekaligus "orang kaya” tersebut. Mereka memaknai diri sebagai agen-agen struktur kelas dalam hierarki berdasarkan total modal yang dimiliki, semakin banyak jumlah modal, kekayaan, yang dimiliki semakin tinggi dan dominan posisinya dalam struktur kelas tersebut. Akibatnya, para pasirah merasa memiliki ruang sosial yang bersifat habitus dalam menghasilkan praktek sekaligus apreasiasi yang terpolakan. Lambanglambang "baru" tersebut bukan saja sebagai lambang kuasa simbolik tersebut, bukan saja lambang politik semata, tetapi juga sebagai bentuk representasi dari lambang kekayaan yang dipunyai. Maka lambang-lambang baru ini melekat dalam hal simbol praktek konsumsi budaya dan gaya hidup, yang kemudian tercermin pada pakaian, makanan, perabot dan kepemilikan serta kesenangan pribadinya, seperti mobil, telepon, sabung ayam dan lelang kue.

Menariknya, lambang-lambang yang sedang berubah ini memainkan bentuk makna dari simbol-simbol menyangkut distinsi, distintion, rasa gengsi, bergengsi yaitu rasa berbeda, sekaligus rasa lebih serta makna tentang diklasifikasikan oleh cara mengklasifikasikan, dibedakan oleh pembeda yang dibuat, pembedaan dengan masyarakat luas marganya serta kontestasi dengan pasirah di marga lainnya namun bentuk lain. Selanjutnya lambanglambang tersebut juga memainkan makna lain simbol kepenganutan diri 
dari bentuk modernitas Eropa yang sedang berjalan bahwa mereka ingin mengadakan pengunjukan diri untuk disamakan paling tidak tidak terlalu jauh dengan para atasannya, orang Belanda. Sebaliknya, dalam pandangan para penduduk marga, juga mengalamai perubahan, para pasirah mereka dianggap tidak lebih sebagai perpanjangan tangan kolonial yang dalam banyak hal semakin meninggalkan mereka, warga marganya.

\section{Referensi}

\section{Dokumen}

Circulaire Residen Palembang No. 326

Ind. Staatsblad No. 109 tahun 1827

Ind. Staatsblad No. 2 tahun 1855

Ind. Staatsblad No. 329 tahun 1903

Ind. Staatsblad No. 420 tahun 1916

Ind. Staatsblad No. 814 tahun 1919

Undang-undang Simbur Cahaya

\section{Artikel Jurnal}

Barendregt, Bart (2006). "A Supernatural Topography of the Southern Sumatran Highlands", Crossroads: An Interdisciplinary Journal of Southeast Asian Studies 18, 1:113-125.

Berg, L. W. C. van den (1894). "Rechtsbronnen van Zuid-Sumatra”, Bijdragen tot de Taal-, Land- en Volkenkunde van Nederlandsch-Indie 43, 5e/9e: 205-273.

Cecchetti, Stephen G \& Georgios Karras (1994). "Sources of Output Fluctuations during the Interwar Period: Further Evidence on the Causes of the Great Depression", The Review of Economics and Statistics 76, 1: 80-82.

Elmhirst, Rebbecca (2011). "Migrant pathways to resource access in Lampung's political forest: gender, citizenship and creative conjugality”, Geoforum 42, 2: 173-183.

Gunther, Th. O. B. (1926). "De Marga-Raden in Palembang”, Locale Belangen 35: 1225.

Hoven, W. (1926). "Een Nieuwe Bijdrage tot de Kennis van het Shamanisme bij de Pasemahers”, Bijdragen tot de taal-, land- en volkenkunde 82, 1: 384-02.

J. A. Kurniawan (2008). "Hukum Adat dan Problematika Hukum Indonesia", Majalah Hukum "Yuridika" 23, 1.

Kathirithamby-Wells, J. (1986). "Royal Authority and the "Orang Kaya" in the Western Archipelago, circa 1500-1800”, Journal of Southeast Asian Studies 17, 2: 256-267.

(1993). "Hulu-Hilir Unity and Conflict: Malay Statecraft in East Sumatra Before the Mid-Nineteenth Century”, Archipel 45: 77-96.

Prins, M. J. (1935). “Aantekeningen over voor-Islamitiesch volks- geloof onder de Oeloeneezen in Palembang”, Koloniaal Tijdschrift 24: 153-175.

Swaab, J. L. M. (1916). "Beschrijving der Onderafdeeling Redjang”, Bijdragen tot de Taal-, Land-en Volkenkunde van Nederlandsch-Indie 72, 3de/4de: 460-554.

Reuter, Thomas (1992). "Precedence in Sumatra: an Analysis of the Construction of Status in Affinalrelations and Origin Group”, Bijdragen tot de Taal-, Land- 
en Volkenkunde 148, 3de/4de: 489-520.

Wisseman, Christie, J. (1995). "State Formation in Early Maritime Southeast Asia: A Consideration of the Theories and the Data", Bijdragen tot de Taal-, Landen Volkenkunde 151, 2: 235-288.

Wilken, G. A. (1888). "Verbreiding van het Matriarchaat op Sumatra”, Bijdragen tot de Taal, Land-en Volkenkunde van Nederlandsch-Indie 37, 2de: 163-215.

\section{Buku}

Bambang Purwanto (1992). From Dusun to the Market: Native Rubber Cultivation in Southern Sumatra, 1890-1940 (Desertasi, SOAS University of London).

Bosch, Army van den (1941). The Dutch East Indies, its Government, Problems and Politics, Los Angeles: Berkeley University.

Bronson, Bennet (1979). "The Late Prehistory and Early History of Central Thailand with Special Reference to Chansen", dalam: R. B. Smith \& W. Watson (eds) (1979). Early Southeast Asia. New York: Oxford University Press, hlm. 315-37.

Dedi Irwanto (2010). Venesia dari Timur: Memaknai Produksi dan Reproduksi Simbolik Kota Palembang dari Kolonial sampai Pascakolonial. Yogyakarta: Penerbit Ombak.

Djoko Soekiman (2000). Kebudayaan Indis dan Gaya Hidup Masyarakat Pendukungnya di Jawa: Abad XVIII-Medio Abad XX. Yogyakarta: Yayasan Bentang Budaya.

Bourdieu, Pierre (1995). Free Exchange. Stanford: Stanford University Press.

Collins, William Augustus (1979). Besemah Concepts: A Study of the Culture of a People of South Sumatra (Disertasi, University of California, Berkeley).

Fadly Rahman (2011). Budaya Kuliner di Indonesia Masa Kolonial 1870-1942. Jakarta: Gramedia Pustaka.

Geertz, Clifford (1980). Negara: The Theatre State in 19th Century Bali. New Jersey: Princeton University Press.

Jaspan, M. A. (1964). From Patriliny to Matriliny: Structural Change Among the Redjang of Southwest Sumatra (Disertasi, Australian National University, Canberra).

Johny A. Khusyairi \& Freek Colombijn (2014). "Moving at a Different Velocity: The Modernization of Transportation and Social Differentiation in Surabaya in the 1920s", dalam: Freek Colombijn dan Joost Coté (eds). Cars, Conduits, and Kampongs: The Modernization of the Indonesian City, 1920-1960. Leiden: Brill, hlm. 251-271.

Marsden, William (1966/2013). A History of Sumatra: 3rd ed. / Sejarah Sumatera (terj.). Kuala Lumpur - Jakarta: Oxford University Press - Komunitas Bambu.

Mestika Zed (2003). Kepialangan Politik dan Revolusi: Palembang 1900-1950. Jakarta: LP3ES.

Munoz, Paul Michel (2006). Early Kingdoms of the Indonesian Archipelago and the Malaya Peninsula. Singapore: Paperback.

Peeters, Jeroen (1997). Kaum Tuo-Kaum Mudo: Perubahan Religius di Palembang. Jakarta: INIS.

Sobel, M. E. (1981), Lifestyle and Social Structure: Concept Definitions and Analyses. New York: Academic Press.

Sri Margana \& Nursam (ed.) (2010). Kota-Kota di Jawa: Identitas, Gaya Hidup dan Permasalahan Sosial. Yogyakarta: Penerbit Ombak.

Taylor, Jean Gelman (2005). "Kostum dan Gender di Jawa Kolonial Tahun 1800- 
1940", dalam: Nordholt, Henk Schulte, Outward Appearence: Trend, Identitas, Kepentingan. Yogyakarta: LkiS.

Sakai, Minako (1997). "Remembering Origins: Ancestors and Places in Gumai Society of South Sumatra, Indonesia", dalam: James J. Fox (eds). The Poetic Power of Place: Comparative perspectives on Austronesian ideas of locality. Canberra: Department of Anthropology, Research School of Pacific and Asian Studies, The Australian National University, hlm. 42-66.

Taylor, Jean Gelman (2003). Indonesia: Peoples an Histories. New Haven and London: Yale University Press.

van Peursen, Cornelis Anthonie, \& Dick Hartoko (1976). Strategi Kebudayaan. Yogyakarta: Penerbit Kanisius.

Weber, Max (1993). The Sociology of Religion. Boston, Massachusetts. USA: Beacon Press.

Wellan, J. W. J. (1932). Zuid-Sumatra: Overzicht van de Gewesten Djambi, Palembang, de Lampoengsche Districten en Bengkoelen. Wegeningen: H. Veenman \& Zoon.

Watson Andaya, Barbara, To Live As Brothers: Southeast Sumatra in the Seventeenth and Eighteenth Centuries. Honolulu: University of Hawaii Press, 1993.

Wessing, Robert (2003). "The Shape of Home: Spatial Ordering in Sundanese Kampung”, dalam: Reimar Schefold, Peter Nas \& Gaudenz Domenig (eds). Transformation of Traditional Houses and Settlements in Indonesia. Leiden: KITLV Press. hlm. 199-250.

Wolters, O. W. (1982). History, Culture and Region in Southeast Asian Perspectives. Singapore: Institute of Southeast Asian Studies.

Woelders, M.O. (1975). Het Sultanaat Palembang 1811-1825. 's-Gravenhage: Martinus Nijhoff. 